


\title{
twórczość Piotra Pazińskiego a praktyki codzienności
}
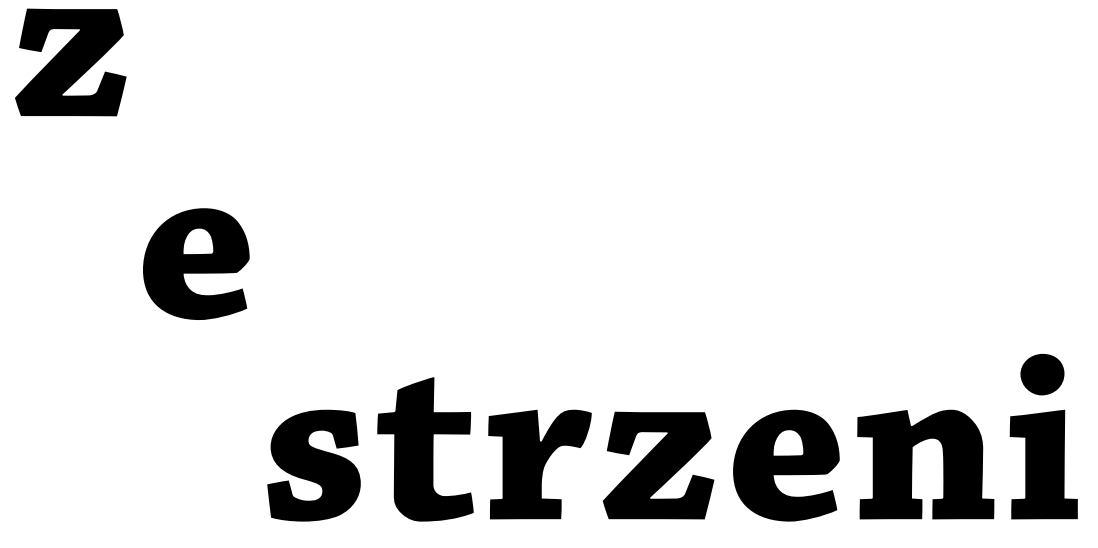

Cezary Rosiński

Marta Mizuro w swojej recenzji Pensjonatu Piotra Pazińskiego zasugerowała, że mieszkańcy żydowskiego domu wypoczynkowego, który odwiedza główny bohater, mogą być nie tyle faktycznie spotkanymi dawnymi znajomymi, ile wytworami jego pamięci, duchami zamieszkującymi to miejsce. Ta interpretacyjna wątpliwość pozwala spojrzeć na cały prozatorski dorobek autora jak na wytwarzanie przestrzeni dziś już nieobecnej, ale ciągle stanowiącej jedną z warstw miejsca, jej miniony charakter. 
Aby ta postawiona na wstępie interpretacyjna wątpliwość zyskała kształt rzetelnej lektury, należy określić wstępne założenia. Przestrzeń performatywna, zgodnie z sugestią Eriki Fischer-Lichte, rozumiana będzie jako ulotna i przemijająca, nie istniejąca przed, poza czy po przedstawieniu, lecz powstająca w trakcie przedstawienia i dzięki niemu. Nie należy też utożsamiać jej z przestrzenią, w której owo przedstawienie się wydarza ${ }^{1}$. Dla jasności wywodu przedstawieniem nazywał będę wszystkie działania podejmowane przez bohatera. To właśnie on jest trzecim elementem równania - bohater określany jako mocny podmiot performatywny, tworzący się w działaniu, będący inicjatorem i sprawcą zmian². Skupienie uwagi na kwestii sprawczości pozwala na pojawienie się w refleksji zagadnień związanych z praktyką i działaniem, przywołuje więc temat przestrzeni i wszelkich aktywności podmiotu kierowanych wobec niej.

Celem wyprawy głównego bohatera, będącego jednocześnie narratorem, jest podwarszawski pensjonat, goszczący przeważnie Żydów, do którego przyjeżdżał wraz z babcią, jeszcze jako małe dziecko. Udaje się on na wędrówkę w dwojakim rozumieniu, wpierw - w sensie fizycznym i geograficznym, dociera na prowincję, by odwiedzić miejsce letniskowe, gdzie po raz pierwszy pokonywał leśne trasy, eksplorował zakamarki obcego budynku i spotkał wielu starych ludzi. Teraz chce sprawić, by to miejsce ożyło powtórnie dawnym życiem - i to jest drugi rodzaj podróży: pamięciowy, wyobrażeniowy, odtwórczy i wreszcie - wytwórczy ${ }^{3}$. Mężczyzna otwiera się na inność tego miejsca, czego efektem jest wędrowne wygnanie z teraźniejszości i realnej przestrzeni. Dopiero wtedy może przywrócić to, co nieobecne dziś w znajomym miejscu4; stąd bowiem bierze się jego poczucie wyobcowania, pewnej nieadekwatności i pesymistyczna świadomość tego, że to, co przemija, jest stare i pozbawione szans na kontynuację ${ }^{5}$.

Najbardziej problematyczna w Pensjonacie pozostaje właśnie kwestia zniewolenia bohatera przez przeszłość, jego niemożność odłączenia się od porządku przodków i jednoczesna chęć pozostania wśród nich. Bezimienny mężczyzna jest „ostatnim z łańcucha pokoleń, uczepionym na samym końcu" (P 134), jego działania prowokowane są niejako niesamodzielnością i koniecznością. Musi żyć życiem umarłych, „ze swoim piętnem tego, co było i co z chwilą, kiedy odeszli, na powrót zapadło się w nicość. Ich życie i moje - mówi bohater - wśród cieni, pośród duchów i z duchami - zamiast promieni świeżego słońca" (P 74). Pod koniec powieści próbuje przecież uciekać, ale nie może, trzymany przez przodków w stalowym uścisku, który przykuwa go do miejsca i siłą włącza do pokolenia jego babci. Skazany na mentalne tkwienie w pensjonacie, stara się przywrócić do życia opuszczony budynek - „wszystko, co tutaj robię, to archeologia pamięci zapadłej w mroku" (P 73), to możliwość śnienia o miejscu. Brak łączy

${ }^{1}$ Zob. E. Fischer-Lichte, Estetyka performatywności, przekł. M. Borowski, M. Sugiera, Kraków 2008, s. 174.

2 Zob. E. Domańska, „Zwrot performatywny” we współczesnej humanistyce, „Teksty Drugie” 2007, nr 5, s. 56.

${ }^{3}$ Zob. Ł. Najder, Z pamięci, „Tygiel Kultury” 2010, nr 4/6, s. 169-170; M. Olszewski, W gabinecie figur woskowych, „Akcent” 2010, nr 4, s. 114.

${ }^{4}$ Zob. M. de Certeau, Wynaleźć codzienność. Sztuki działania, przekł. K. Thiel-Jańczuk, Kraków 2008, s. 107-108.

${ }^{5}$ Zob. P. Paziński, Pensjonat, Warszawa 2010, s. 103. Wszystkie cytaty pochodzą z niniejszego wydania - w tekście oznaczone jako P z numerem strony. 
się tutaj z subiektywnością - wszystko, co pojawia się na scenie wspomnienia, nosi wyraźne znamię indywidualności. Paziński ma świadomość tego, że miejsca, w których żyjemy, są obecnościami nieobecności, musi zatem pokazać to, co już niewidoczne ${ }^{6}$.

Ale aby to zrobić, zmuszony jest znaleźć punkt wyjścia, zbadać materialność, określić status przestrzeni teraźniejszej. Oto reakcja głównego bohatera, gdy dociera do pensjonatu:

Drzwi wejściowe zamknięte. Dzwonek chyba nie działa, w każdym razie nikogo nie udało się nim zawezwać. Cały budynek zdawał się pogrążony we śnie. Zatrzaśnięte okna, na tarasie nikogo, pusto na balkonach (P 10).

$\mathrm{Na}$ kartach powieści wielokrotnie pojawiają się sygnały tego, że budynek jest opuszczony: „hol i jadalnia trwają bezludnie” (P 26), „cicho tu (...). Martwo” (P 29), zauważa kierownik pensjonatu - jedyny obok pojawiającego się pod koniec utworu pana Jakuba, którego można uznać za żyjącego, wreszcie: „wszystko trwało tutaj w uśpieniu” (P 70). Wątpi także narrator, pyta: „ale czy tu jeszcze ktokolwiek został?” (P 104), jego odczucia potęguje z pewnością wszechobecna mgła, w której tonie dom wczasowy ${ }^{7}$ Końcowości pensjonatu przeciwstawiona zostaje, reprezentująca wszelkie siły witalne natura, która „pragnie zemścić się na starych murach za całą ich nędzę i niedołęstwo i pochłonąć ze szczętem, żeby nie pozostało po nich nawet najlżejsze drgnienie pamięci" (P 127).

Kontakt z samym budynkiem wywołuje reakcję, puste pomieszczenia wciąż wypełnione są przecież wypowiadanymi niegdyś zdaniami. Może właśnie dzięki tej schyłkowości wszystko to, co przeżył, wraca do narratora, przeszłość na każdym kroku zaskakuje go i dopada. Wzrasta w nim gorzka świadomość ulotności dziedzictwa, poczucie, że istnieje ono tylko wtedy, gdy istnieje on sam. Przestrzeń wspomnień i widm, cały ten spektakl, rodzi się na styku jego pamięci i odnalezionych w budynku artefaktów. Opowiedziana, a właściwie: odegrana na kartach Pensjonatu historia to ostatni moment obecności przed unicestwieniem. Mężczyzna wykorzystuje tę szansę, dlatego że przywracanie dawnej postaci miejsca - choćby tylko jako przedstawienia wyobraźni - potrzebne jest mu po to, by zachować ciągłość, ciąży na nim przecież przymus przekazania świadectwa kolejnym generacjom. Poniewczasie zdaje sobie sprawę, że powinien o takie rzeczy pytać, teraz nie ma już kogo, wszyscy odeszli. Istota ciągłości polega przecież na tym, że każdy element znajduje się wewnątrz, między tym, co wcześniej, a tym, co później. Znalezione fotografie z epoki, prehistoryczne gazety, nawet nieaktualna książka telefoniczna z żydowskimi mieszkańcami muszą pozostać czytelne, ktoś powinien umieć je wyjaśnić, wydrzeć anonimowości i zapomnieniu. Dlatego właśnie pojawiają się duchy dawnych mieszkańców domu wczasowego, a to, co je charakteryzuje, to jednak nie obecność, a jedynie „zjawianie się”. Te postaci czasu minionego zostają zaktualizowane wtedy, gdy bohater decyduje się przywrócić dawną rzeczywistość pensjonatu. Stan, w którym przebywają, to potencjalność. Miejsce, twierdzi Michel de Certeau, istnieje wówczas, gdy jest nawiedzane przez rozliczne przyczajone w nim duchy, które można „wywoływać”. Ten „młody człowiek” - jak nazywają bohatera duchy pensjonatu - wykorzystuje wielowarstwo-

\footnotetext{
${ }^{6}$ Zob. M. de Certeau, Wynaleźć codzienność..., dz. cyt., s. 109
}

${ }^{7}$ Zob. P. Paziński, Pensjonat, dz. cyt., s. 70, 89, 106. 
wość przestrzeni domu wczasowego, jego palimpsestowość, odnajduje przejścia prowadzące do uprzedniej rzeczywistości tego miejsca. Czuje przecież, że „zaraz obok, za ścianą, chowają się oni" (P 101), że żyją w utajeniu.

Praca wytwórcza i praca pamięci potrzebują ruchu, odciśnięcia piętna własnej obecności w zastanej przestrzeni, dlatego bohater Pazińskiego jest dynamiczny; wpierw podróżuje do pensjonatu, następnie przemieszcza się jego korytarzami, spaceruje po otaczającym budynek lesie. Dzięki jego sprawczości, odgrywaniu wspomnień, urzeczywistnia przestrzeń. To, co charakteryzuje dom wczasowy stworzony przez działanie bohatera, tę - chciałoby się powiedzieć - „wychodzoną przestrzeń”, to zaistnienie i pojawienie się, nie mamy już przecież do czynienia z niszczejącym i opuszczonym budynkiem. Te pojęcia - które de Certeau uznaje za przejawy indywidualnej sprawczości - oddają pierwszeństwo chodzeniu, to dzięki niemu elementy przestrzenne zostają przekształcone, dając im szanse rozwoju i tworząc przestrzenne „wyrażenia".

W sposób dużo bardziej wyrafinowany przestrzeń wytwarzana jest w Ptasich ulicach, na które składają się cztery opowiadania, wszystkie jednak łączą się i przenikają, przez co zbiór najlepiej czytać jako jedną opowieść w kilku odsłonach. A króluje tutaj nieobecność, znikanie, szukanie śladów oraz zbłądzenie w labiryncie ludzkich wspomnień i wielkiej historii $\mathrm{w}$ indywidualnym wydaniu. Paziński opisuje żydowski świat, który - nie istniejąc - ukryty jest na marginesie, na styku rzeczy, gdzie szwy i pęknięcia są bardziej widoczne. To świat cieni, przenikających strumieni delikatnego światła, które pojawiają się wszędzie tam, gdzie rzeczywistość została zaprojektowana na siłę, a przeświadczenie o tym, że wszystko można zacząć od nowa, wygrało tylko pozornie. Odtwarza, a może właśnie tworzy światy, które - wykluczając się wzajemnie - otwierają sekretne przejścia, przesmyki, pozwalające zobaczyć więcej, złożyć całość z rozsypanych w powojennej Warszawie śladów. Miejsca, które opisuje, zakamarki, nawet siatka przecznic nie przywierają do gruntu. Miastu konceptualnemu, wytworowi teorii, racjonalistycznego funkcjonalizmu i historii, zupełnie jak w koncepcji de Certeau, przeciwstawione zostaje miejsce doświadczane w praktyce - obecne, choć niewidzialne, anihilowane z map, emanujące życiem pośmiertnym tak intensywnym, że realność współczesności zanika i blednie, oddając życie fenomenom, prywatne, „metaforyczne miasto przenika w ten sposób do zrozumiałego tekstu zaplanowanego i czytelnego miasta".

"Gry kroków kształtują przestrzeń. Stanowią osnowę miejsc"10, powie de Certeau, odnosząc nas ponownie do zagadnienia ruchu, a ten odbywa się w Ptasich ulicach na znacznie większej przestrzeni, niż miało to miejsce w Pensjonacie. Jego terenem jest Warszawa, dawne ulice: Orla, Gęsia, Kacza, a ruch pozwala wypłynąć temu, co zostało wykluczone na poziomie projektu urbanistycznego ${ }^{11}$, „odpady” funkcjonalistycznej administracji w postaci żydowskiej przeszłości tych miejsc wracają z wygnania.

\footnotetext{
${ }^{8}$ Zob. M. de Certeau, Wynaleźć codzienność..., dz. cyt., s. 99, 100.

${ }^{9}$ Tamże, s. 95.

${ }^{10}$ Tamże, s. 98.

${ }^{11}$ Tamże, s. 96.
} 
Najbardziej widoczne jest to w opowiadaniu Manuskrypt Izaaka Feldwurma - interesującym skrzyżowaniu tekstu i działania, występujących obok siebie, lecz tworzących jednocześnie kontinuum przyczynowo-skutkowe. Oto każdego roku w rocznicę wybuchu powstania w getcie rozpoczyna się rytualne wspominanie Izaaka Feldwurma i jego manuskryptu - zaginionej, a być może w ogóle nieistniejącej powieści globalnej, „książka (...) była niezrównaną panoramą epoki, nawet kilku epok. Wojny i rewolucje powstania i okresy prosperity, narodziny i śmierć - wszystko zlewało się w jeden nurt" (PU 112)12. Od Feldwurma nie było ucieczki, był cieniem, niezbyt wyraźnym, ale prawie namacalnym odbiciem dawnych żydowskich losów. Opowieść o nim przekazywana $z$ ust do ust, ciągle zmieniająca swoje brzmienie legenda przyczyniła się do jego nachalnej obecności. Nie chcąc oddać świata żyjącym, niepokoił wszystkich bez wyjątku, pojawiając się w odległych rejonach miasta, nawiedzając miejsca i znikając niepostrzeżenie.

Bohater opowiadania decyduje się śledzić obecność Feldwurma w teraźniejszej Warszawie, biega za nim po całym mieście, powtarzając kroki i działania żydowskiego pisarza. Przestrzeń zostaje wytworzona poprzez korelację chodzenia po mieście i aktu mówienia, manuskrypt i jego rytualne wspominanie towarzyszą wędrówkom Feldwurma i bezimiennego bohatera. Akt chodzenia - dowodzi de Certeau - jest dla miasta tym, czym wypowiadanie dla języka, to proces zawłaszczania systemu topograficznego przez pieszego ${ }^{13}$, a $\mathrm{w}$ przypadku Pazińskiego - to przestrzenna realizacja Warszawy. Innymi słowy: chodząc po mieście w poszukiwaniu Feldwurma, poruszając się tymi samymi ścieżkami co on, wytwarza taką przestrzeń, która wywodzi się na poły z obecnego wyglądu miasta, na poły z wyobrażeń, wspomnień i dokumentów. Staje się ona szczeliną, tunelem łączącym obecne $\mathrm{z}$ minionym.

Obie książki Pazińskiego spaja jedna z wędrownych figur stylistycznych. Jest nią synekdocha, która „rozciąga jakąś część przestrzeni, każąc jej odgrywać rolę czegoś «większego» i podstawić się na jej miejsce"14. Wytwarzana przez Pazińskiego przestrzeń odkrywa jej palimpsestowy charakter, wybierając spośród wszystkich potencjalności jedną realizację. Przestrzeń w Pensjonacie i Ptasich ulicach jest rozciągła, całość zostaje zastąpiona fragmentami, pozbieranymi skrupulatnie resztkami pamięci. Synekdocha zagęszcza je, powiększając szczegół i pomniejszając zarazem całość. Oznacza to, że wytworzona przestrzeń ma ambicje globalne, staje się - tutaj, w tej chwili, w tym przedstawieniu pamięci i wyobraźni - jedyną pełną realizacją.

Casus Pazińskiego udowadnia, że zwrot performatywny związany jest ze sprawczością nie tylko ludzi. Przestrzeń performatywna - przestrzeń spektaklu - wytwarzana jest zarówno dzięki podmiotowi, jak i przestrzeni geometrycznej, która staje się pojemnikiem dla działań momentalnych. Lecz performatywność zakłada także - pisze Ewa Domańska - powtórzenie, gdyż dopiero wielokrotność jest gwarancją tego, by zjawiska mogły zaistnieć15. Tę wielokrot-

\footnotetext{
${ }^{12}$ P. Paziński, Ptasie ulice, Warszawa 2013. Wszystkie cytaty pochodzą z niniejszego wydania - w tekście oznaczone jako PU z numerem strony.

${ }^{13}$ Zob. M. de Certeau, Wynaleźć codzienność..., dz. cyt.,s. 99.

${ }^{14}$ Tamże, s. 102.

${ }^{15}$ Zob. E. Domańska, „Zwrot performatywny”..., dz. cyt., s. 49
} 
ność w przypadku Pazińskiego zapewnia powtarzalność czytania przestrzeni przez jego bohatera. To z kolei, co autor oferuje czytelnikowi, jest przedstawieniem miejsca stającego się fragmentarycznymi i zwiniętymi historiami, przeszłościami, którym nadaje czytelność, nagromadzonymi czasami, mogącymi się rozwinąć, ale występującymi tutaj raczej jako potencjalne opowieści, zagadki do rozwikłania ${ }^{16}$.

Język dzieła literackiego Paziński formułuje w taki sposób, by nie tylko przedstawić rzeczywistość, lecz także prokurować w niej zmiany. Historia jest odtwarzana i powtarzana. Dodatkowo, jak pisze Anna Krajewska, w literaturze „uwalnia się sen, równie realny, jak złudny, przekształcający zdarzenia, manipulujący sekwencjami obrazów, a przecież także doświadczany fizycznie jako lęk, pożądanie, przerażenie, błogość czy zachwyt" ${ }^{17}$. W akcie czytelniczym wytworzona przestrzeń zostaje uwolniona, nie ogranicza jej już materia tekstu, to dobry punkt wyjścia do tego, by wprawić oglądających w taki stan, jaki poznał sam bohater, zestawiając wspomnienia z rzeczywistym kształtem miejsc. Tym bardziej że akt lektury każdorazowo rozpoczyna przedstawienie wytwarzania przestrzeni od nowa, oddając czytelnikowi należny mu udział i czyniąc z niego współautora, oferuje bowiem materiał do samodzielnego układania. Właśnie dlatego powieści Piotra Pazińskiego można odczytywać nie jako całość, lecz zbiór fragmentów, dający się porządkować za każdym razem inaczej.

${ }^{16}$ Zob. M. de Certeau, Wynaleźć codzienność..., dz. cyt., s. 109.

${ }^{17} \mathrm{~A}$. Krajewska, „Zwrot dramatyczny” a literaturoznawstwo performatywne, „Przestrzenie Teorii” 2012, nr 17, s. 49. 


\section{SEOWA KLUCZOWE:}

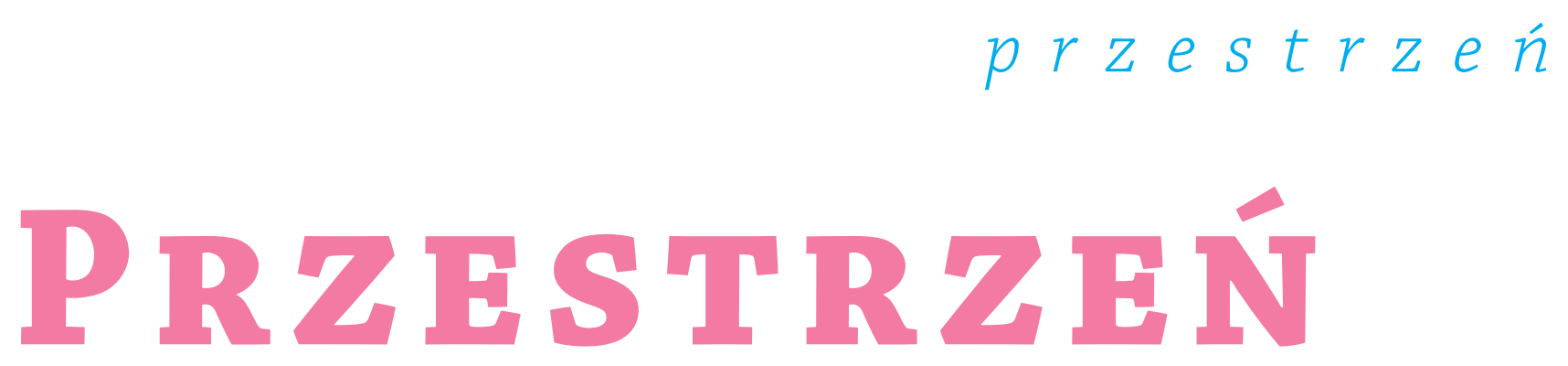

\section{Piotr Paziński}

A B S T R A K T :

Tekst poświęcony twórczości prozatorskiej Piotra Pazińskiego w centrum rozważań umiejscawia performatywną działalność bohaterów, którzy zyskują zdolność wytwarzania przestrzennych sensów, sytuujących się na przecięciu historycznych zaszłości i indywidualnego doświadczenia. Sprawczość postaci zostaje sprzęgnięta z praktykami codzienności w ujęciu Michela de Certeau. Współdziałania bohaterów i przestrzeni rozszerzają kategorię zwrotu performatywnego na sprawczość nie tylko ludzi, lecz także przestrzeni geometrycznej, która - upodmiotowiona - staje się aktywnym uczestnikiem kreowania znaczeń. 
upodmiotowiona

\section{performatywność}

sprawczość
N O T A O A U T O R Z E :

Cezary Rosiński - doktorant na Wydziale Filologii Polskiej i Klasycznej Uniwersytetu im. Adama Mickiewicza w Poznaniu.

Do jego zainteresowań badawczych należy najnowsza proza polska, zagadnienie starości i przestrzeni w literaturze. Jako krytyk literacki współpracuje z „Nowymi Książkami” i „Odrą”. Niedawno ukazała się jego książka Ocalić starość. Literackie obrazy starości w polskiej literaturze najnowszej. 